\title{
PLATYSTACUS ANGUILLARIS.
}

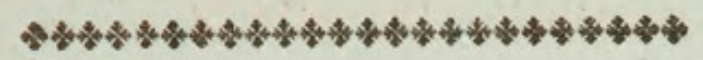

\section{CHARACTER GENERICUS.}

Truncus brevis, depressus. Cauda longa, compressa.

Bloch. ichth. 11. p. 42.

Abdominales.

CHARACTER SPECIFICUS, Ẽc.

PLATISTACUS fuscus, striis longitudinalibus albis, pinna ani, caudæ dorsique secundo connatis.

PLATYSTACUS ANGUILLARIS. P. pinna ani, caudæ dorsique secundo connatis.

Bloch. ichth. 11. p. 49. t. 373.

Platystacum cotylephorum in opere nostro non ita pridem descripsimus. Ab hoc differt species de qua jam agitur capite magis elongato, spinis thoracicis minoribus, præcipue vero acetabulis nullis sub abdomine sitis. Eadem incolit maria quæ Platystacus cotylephorus. 



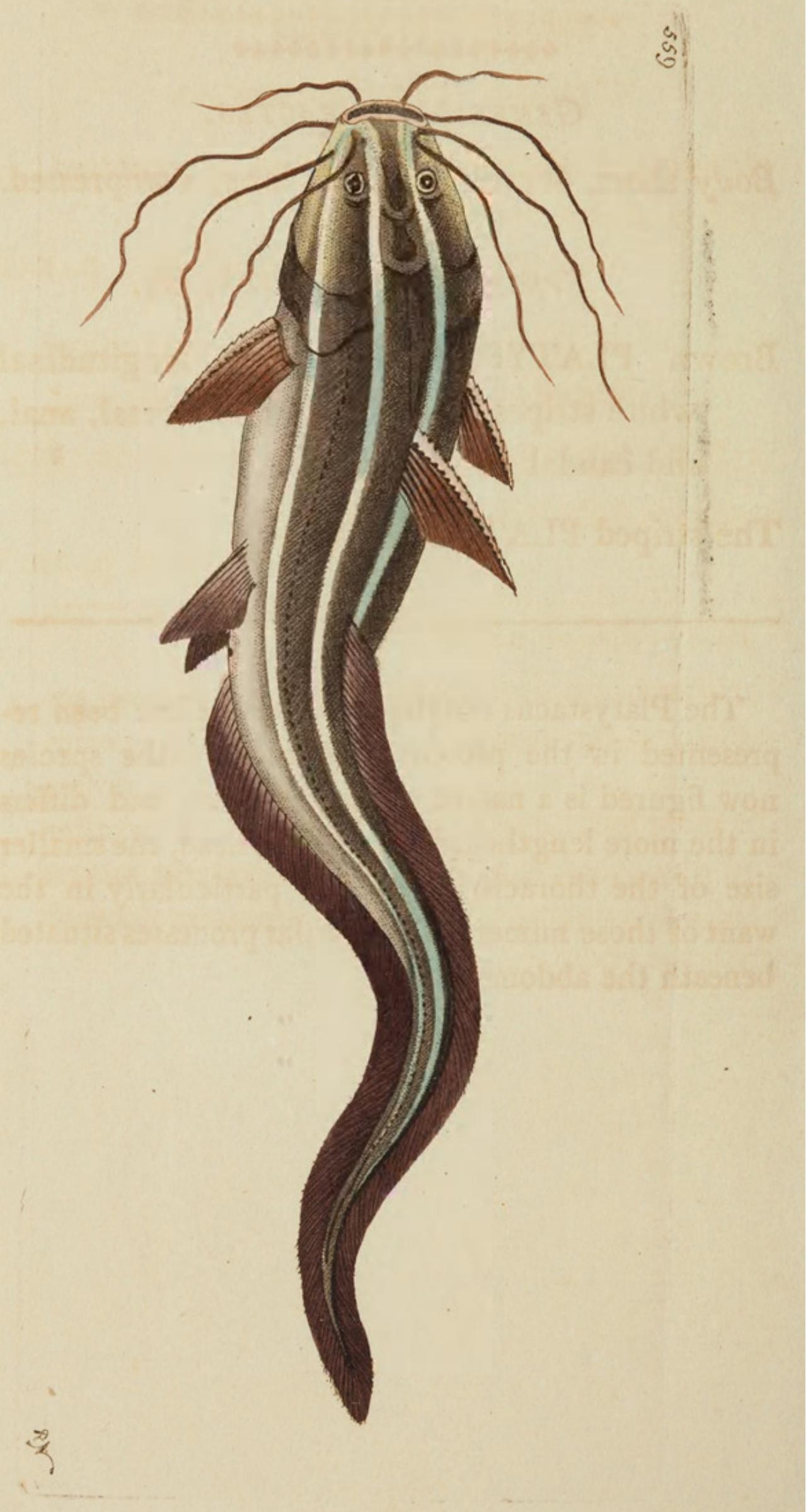


THE'

\title{
EEL-SHAPED PLATYSTACUS.
}

\author{
$44+484 * 4444+484444$ \\ GENERIC CHARACTER.
}

Body short, depressed. Tail long, compressed.

SPECIFIC CHARACTER, छㄷ.

Brown PLATYSTACUS, with longitudinal white stripes, and the second dorsal, anal, and caudal fin united.

The striped PLATYSTACUS.

The Platystacus cotylephorus has before been represented in the present publication: the species now figured is a native of the same seas, and differs in the more lengthened form of the head, the smaller size of the thoracic aculei, and particularly in the want of those numerous acetabular processes situated beneath the abdomen. 


\section{$2 \mathrm{BHL}$ Biodiversity Heritage Library}

Shaw, George. 1803. "The Eel-Shaped Platystacus, Platystacus anguillaris [PI. 559]." The Naturalist's Miscellany 14(CLXI), https://doi.org/10.5962/p.311004.

View This Item Online: https://www.biodiversitylibrary.org/item/278723

DOI: https://doi.org/10.5962/p.311004

Permalink: https://www.biodiversitylibrary.org/partpdf/311004

\section{Holding Institution}

Museums Victoria

\section{Sponsored by}

Atlas of Living Australia

\section{Copyright \& Reuse}

Copyright Status: Public domain. The BHL considers that this work is no longer under copyright protection.

This document was created from content at the Biodiversity Heritage Library, the world's largest open access digital library for biodiversity literature and archives. Visit BHL at https://www.biodiversitylibrary.org. 